\title{
Study on Gender Pay Gap in Secretaries based on Regressions
}

\author{
Yunhao Shi \\ College of Liberal Arts and Sciences, University of Colorado Denver, Denver, Colorado 80214, America \\ yunhao.shi@ucdenver.edu
}

Keywords: gender, pay, empirical study.

\begin{abstract}
The problems of gender inequality and gender differences in social mobility have been respectively received extensive attention from academia. Half of the population in society are constituted by women and they bear the important responsibility of reproduction, modern women have become indispensable talents for promoting the development of industrial society. However, is it equal for women and men in the society? To answer this question, the most direct concern is income. Based on this, the study first summarizes the theory of gender stratification. Then, we use the multiple linear regression method to study the impact of gender on income, at the same time examine the gap between gender and income by controlling of a number of important variables. We find that there is a significant difference in income between men and women, and the men's average income is significantly higher than women's. Moreover, the gender gap is still significant after controlling the control variables we used in this study.
\end{abstract}

\section{Introduction}

Anthony Giddens points that "women seem to be unimportant or there's no need to analysis them while studying the distinction among power, wealth, and influence, but gender itself is a farreaching paradigm of social stratification." [1] Indeed, women constitute half of the population in society and they bear the important responsibility of reproduction, especially, the modern women have become an indispensable talent to promote the development of industrial society. However, is it equality for women and men in the social? The most direct point to answer this question is income. The world's academia or public opinion are very concerned about the problem of income differences in gender, not only in China. Scholars unanimously found that income inequality of gender is widespread no matter in what context of economic system, social culture and social structures, only the degree of inequality is different. While discussing the problem of gender income inequality, people try to explain the existence of gender inequality whether from the economic perspective of income theory or the gender perspective of sociology. The theory of human capital in economics argues that women's investment in their own human capital can be interrupted by the constraints of family responsibilities, while men's human capital can be in continuous investment. So women have a lower return on income than men. Sociology of socialization theory argues that compared to men, women have less efforts in work and returns in income because of the different roles of gender from social cultural.

Based on this, the study first sums up the theory of gender stratification. Then we examine the effect of gender on income through a multiple linear regression approach, with examining the gender income disparity by controlling some important variables. This paper provides a new empirical evidence for the study of gender income disparity.

\section{Gender stratification theory}

The study of the class in Sociology can be traced back to the classical sociological theory period, as the classic social stratification theory are Marx's class stratification theory and Weber's 
hierarchical theory [2]. Gender stratification is not a hierarchical division of economics, politics and so on, but is the hierarchy based on the innate gender. Gender stratification refers to the differ tentation of gender in socioeconomic status and the differentiation within women. In the 1960s and 1970s, the concept of gender was born and became the core concept of feminist movement and research. The feminism refers to the movement and consciousness of women striving for equality in all areas of politics, economy and rights.

Feminist researchers first constructed the concept of gender. There are three stages for studying gender, namely the marginalization period in the 1970s, the academic development period in the 1980s and 1990s and the transitional period from the 1990s to the present. Gender research has received wide attention from society and academia. As an important concept and an analytical category, gender has been formed and becomes with the class, race, national parallel concept, instantly in the subject analysis. Gender is different from physiological gender, it is not innate, but the social construction of gender roles. The gender theory emphasizes the study of women as the main body of development and placing them with men in a common framework. Feminist scholar Harding argues that gender has three connotations: First, the identity of individual gender, that is, the judgment of men and women on their own gender temperament is the most important part of gender identity; Second, the identity of the social structure, that is the construction of cognitive of the gender division which reflected in all aspects of social life; Third, the gender symbol or cultural cognition, that is the gender normative connotation in the specific cultural context [3].

Feminists have put forward their own views on the theory of gender stratification after the construction of the concept of gender. Chaffee is the most important feminist theorist who uses scientific means to explain gender stratification. Chaffee has pointed out that gender stratification is ultimately related to the division of labor at the macro level. Because of the gender division of labor, men have more resources than women, which made men have more power at the micro level. As a result, women become more difficult to compete with men outside the home, thus further maintaining a gender-level gender division. Gender bias is non-stop reproduced in this process, so that people continually perceive gender inequality in the family and work [4].

Mitchell's female stratification theory emphasizes the effects of production, fertility, sex, and child on women. The theory argue that women are in the position of naturally being exploited in the production and fertility, the dual standards of gender in sexuality make sexual liberation did not achieve equality, then the role of female in the family will not be changed, and the real equality with men will not be achieved. Mitchell also predicts that the gender inequality will be greatly improved when both sexes are no longer the dominant factor in development. But the reality is that women are subject to the dual oppression from the labor market and family [5].

In the explanation framework of gender hierarchical, feminism consider that the gender relations of social giving and constructing are the source of gender differences for gender stratification. As shown in Table 1, there are obvious differences between the three classical theoretical schools of the West and the feminist interpretation of gender stratification. In the analysis of units, Marxism and Weber schools regard the whole family as a unit and mainly emphasize the social stratification of the whole class, while gender stratification is an integral part of the overall social stratification. Durkheim schools consider that the family division of within male and female is also a gender stratification. The feminist view argues that women, as independent individuals, are subject to male oppression both at home and in the labor market. In terms of analytical tools, The Marxism schools continues the framework of exploitation and been exploited, and consider that the relationship between women and men is also a manifestation of the exploitation of women, Weber schools believe that women are at the disadvantage because of lacking the possession of resources, or even as a resource possessed by men. The Durkheim schools argues that social division of labor causes different divisions in occupation and family between male and female, which results in gender differences. Feminism analyzes gender differences from the social construction of gender. In terms of the source of gender differences, the Marxism schools, the Weber schools and the Durkheim schools have pointed out that gender differences in gender led to gender differentiation and inequality, with the biggest difference, feminism emphasis that the social role construction of 
gender is the root cause of differences. The attitude towards gender differences, Marxism schools believe that it is also a part of the elimination of social inequality to eliminate the gender differences and achieve gender equality, Weber schools maintained a consistent principle of value neutrality, Durkheim schools believe that in fact gender division of labor and inequality have a positive function on the development of society, which is the results of the group interests differentiation and mutual restraint, while the fundamental purpose of feminism is to eliminate gender differences. In terms of solutions, Marxism schools believe that women's extensive participation to social labor to achieve economic independence is the fundamental way to solve the inequality of women, Weber schools believe that with the development of the market economy and advanced social structure ,gender inequality will be gradually reduced, Durkheim schools believe that the social division of labor is also a way of mutual restraint, the conflict groups in the process of mutual restraint will achieve equality, Feminism believes that the achievement of gender equality requires the reconstruction of gender roles in society.

Table 1 Comparison of Gender Stratification Theory

\begin{tabular}{|c|c|c|c|c|c|}
\hline & $\begin{array}{l}\text { Analysis } \\
\text { Unit }\end{array}$ & $\begin{array}{l}\text { Analyzing } \\
\text { Tool }\end{array}$ & $\begin{array}{l}\text { Source of } \\
\text { Gender } \\
\text { Difference } \\
\end{array}$ & $\begin{array}{l}\text { Attitude toward } \\
\text { Difference }\end{array}$ & Solutions \\
\hline $\begin{array}{l}\text { Marxism } \\
\text { Schools }\end{array}$ & family & $\begin{array}{c}\text { exploit/ } \\
\text { be exploited }\end{array}$ & physiology & $\begin{array}{l}\text { eliminate } \\
\text { differences }\end{array}$ & $\begin{array}{c}\text { women } \\
\text { participate to } \\
\text { social labor }\end{array}$ \\
\hline $\begin{array}{l}\text { Weber } \\
\text { Schools }\end{array}$ & family & $\begin{array}{l}\text { resource } \\
\text { possession }\end{array}$ & physiology & value neutrality & $\begin{array}{l}\text { advanced market } \\
\text { economy }\end{array}$ \\
\hline $\begin{array}{l}\text { Durkheim } \\
\text { Schools }\end{array}$ & individual & $\begin{array}{c}\text { social } \\
\text { division }\end{array}$ & physiology & $\begin{array}{l}\text { positive } \\
\text { function }\end{array}$ & $\begin{array}{c}\text { restraint of labor } \\
\text { division }\end{array}$ \\
\hline Feminism & individual & gender & social & $\begin{array}{l}\text { eliminate } \\
\text { differences }\end{array}$ & $\begin{array}{l}\text { reconstruct } \\
\text { gender }\end{array}$ \\
\hline
\end{tabular}

\section{Data description}

The original data is form the American Community Survey and detailed information is available through the Integrated Public Use Microdata Series (IPUMS) at the University of Minnesota at https://usa.ipums.org/usa-action/variables/OCC2010\#codes_section. According to the scale of the dataset and the purpose of this study, we only selected part of the data as our main regression sources. The selected occupation is Secretaries and Administrative Assistants, with the code of 5700. Totally, there are 102 variables in our dataset. However, we will only use 9 of them in our regression model, including sex, age, education attainment, usual hours worked per week, class of worker, metropolitan status, industry and state. Detailed information is shown in the Table 2 below.

Table 2 Data description

\begin{tabular}{|c|c|c|}
\hline Name & Label & Type \\
\hline sex & Sex & byte \\
\hline age & Age & int \\
\hline educ & Education attainment [general version] & byte \\
\hline uhrswork & Usual hours worked per week & byte \\
\hline classwkr & Class of worker [general version] & byte \\
\hline metro & Metropolitan status & byte \\
\hline ind & Industry & int \\
\hline statefip & State (FIPS code) & byte \\
\hline
\end{tabular}




\section{Results \& Discussions}

The dataset contains 1287 men and 26253 women. Based on the dataset, we carry on eight multiple regressions, setting personal income as explanatory variable, sex as independent variable and other variables as control variable. The empirical results are shown in the Table 2.

Table 3 The results of regressions

\begin{tabular}{|c|c|c|c|c|c|c|c|c|c|}
\hline & i. & ii. & iii. & iv. & $\mathrm{V}$. & vi. & vii. & viii. & ix. \\
\hline sex & $\begin{array}{c}- \\
0.06^{* *} \\
(0.02)\end{array}$ & $\begin{array}{c}- \\
0.11^{* * *} \\
(0.02)\end{array}$ & $\begin{array}{c}- \\
0.09 * * * \\
(0.02)\end{array}$ & $\begin{array}{c}- \\
0.05^{* *} \\
(0.02)\end{array}$ & $\begin{array}{c}- \\
0.05^{* *} \\
(0.02)\end{array}$ & $\begin{array}{c}- \\
0.04^{*} \\
(0.02)\end{array}$ & $\begin{array}{c}- \\
0.04 * \\
(0.02)\end{array}$ & $\begin{array}{c}- \\
0.03 * \\
(0.02)\end{array}$ & $\begin{array}{c}- \\
0.04^{*} \\
(0.02)\end{array}$ \\
\hline age & & $\mathrm{X}$ & $\mathrm{X}$ & $\mathrm{X}$ & $\mathrm{X}$ & $\mathrm{x}$ & $\mathrm{X}$ & $\mathrm{X}$ & $\mathrm{X}$ \\
\hline educ & & & $\mathrm{X}$ & $\mathrm{X}$ & $\mathrm{X}$ & $\mathrm{X}$ & $\mathrm{X}$ & $\mathrm{X}$ & $\mathrm{X}$ \\
\hline uhrwork & & & & $\mathrm{x}$ & $\mathrm{X}$ & $\mathrm{x}$ & $\mathrm{X}$ & $\mathrm{X}$ & $\mathrm{x}$ \\
\hline classwkr & & & & & $\mathrm{X}$ & $\mathrm{x}$ & $\mathrm{X}$ & $\mathrm{X}$ & $\mathrm{x}$ \\
\hline metro & & & & & & $\mathrm{X}$ & $\mathrm{X}$ & $\mathrm{X}$ & $\mathrm{X}$ \\
\hline ind & & & & & & & $X$ & $X$ & $X$ \\
\hline statefip & & & & & & & & $\mathrm{X}$ & $\mathrm{x}$ \\
\hline $\begin{array}{c}\text { Yunhao’s } \\
\text { model } \\
\text { (Raced) }\end{array}$ & & & & & & & & & $\mathrm{X}$ \\
\hline Adjusted $\mathrm{R} \wedge 2$ & 0 & 0.05 & 0.06 & 0.07 & 0.08 & 0.1 & 0.15 & 0.17 & 0.17 \\
\hline $\begin{array}{c}\text { Observation } \\
\text { count }\end{array}$ & 27540 & 27540 & 27540 & 27540 & 27540 & 27540 & 27540 & 27540 & 27540 \\
\hline $\mathrm{t}$ & -2.36 & -4.79 & -3.9 & -2.31 & -2.02 & -1.74 & -1.89 & -1.43 & -1.51 \\
\hline
\end{tabular}

Note: *represents significance at the $10 \%$ level, $* *$ represents significance at the $5 \%$ level, and $* * *$ represents significance at the $1 \%$ level.

From the results shown in Table 2, we can find some interesting points. First, the coefficients of these regression models keep changing. The coefficients are all negative and represent the relationship between sex and income wage is negative, holding other variables constant. The absolute value of the coefficient increase from 0.06 to 0.11 when adding a variable of age, which shows that the effect of sex on wages increases. And then, the absolute values of coefficient keep decreasing as adding usual work hours, worker class, metro, industry, and state one by one to this modes. When adding the variable "race" to my model, the absolute value of coefficient increases from 0.03 to 0.04 . During the process, we can still say that the effect of sex on wages has become smaller and smaller.

Second, the significant of my regression models is changing. When adding the variable age and education, the decreasing p-values indicates that sex could be more and more statistically significant in explaining wages. Then, when I add usual work hours, worker class, metro, industry, state and race to my models, the p-value becomes larger. It means that sex has become insignificant in explaining wages.

Third, since the coefficients of my regressions models are not equal to 0 , it shows that when holding other variables constant, sex has effect on the wages. Thus, the gender pay gap in my occupation remains.

\section{Conclusion}

In this paper, we examine the impact of gender on income. The data used in this paper, like most studies, confirm the existence of income inequality in both sexes. Moreover, after controlling some of the control variables used in this study, the gender gap is still significant. 
Sociological quantitative studies include two types of horizontal and vertical research, Vertical research refers to the analysis of data collected over a continuous period of time, which can be understood the changes and the development of the problems in different periods of research, and also has more advantages in time logic; Horizontal research is an analysis of the data collected at a time point for a problem, and it is difficult to compare in time sequence. The data of this study are horizontal research data. In the future study, we hope to continue this problem by using longitudinal research data to find the gender gap in the development process.

\section{References}

[1] Giddens, A., Duneier, M., Appelbaum, R. P., \& Carr, D. (1996). Introduction to sociology. WW Norton.

[2] Bendix, R. (1974). Inequality and social structure: a comparison of Marx and Weber. American Sociological Review, 149-161.

[3] Harding, S. G. (1986). The science question in feminism. Cornell University Press.

[4] Chafetz, J. S. (1990). Gender equity: An integrated theory of stability and change (Vol. 176). Sage Publications.

[5] Dwyer, S. (1996). Who's Afraid of Feminism. Dialogue, 35(02), 327-342. 